\title{
Discussion as a modern educational technology in teaching English
}

\section{A discussão como uma tecnologia educacional moderna no ensino de inglês}

\section{Discusión como tecnología educativa moderna en la enseñanza del inglés}

\author{
Andrey Aleksandrovich Vetoshkin ${ }^{1}$ iD , Svetlana Ivanovna Piskunova $^{1}$ iD, \\ Lyudmila Mikhailovna Boyarkina1 $^{1}$ (D), Elena Aleksandrovna Davydova ${ }^{1}$ (D), \\ Olga Aleksandrovna Nikishina ${ }^{1}$ (D)
}

${ }^{1}$ Evseviev Mordovia State Pedagogical University, Saransk, Russia.

Corresponding author:

Andrey Aleksandrovich Vetoshkin

Email: andrey.a.vetoshkin@yandex.ru

How to cite: Vetoshkin, A. A., Piskunova, S. I., Boyarkina, L. M., Davydova, E. A., \& Nikishina, O. A. (2022). Discussion as a modern educational technology in teaching English. Revista Tempos e Espaços em Educação, 15(34), e17324.

http://dx.doi.org/10.20952/revtee.v14i33.17324

\begin{abstract}
The main function of the education connected with foreign languages is to provide the learners with qualified knowledge according to their future carrier. The paper deals with the problem of methodological organization of teaching a foreign language in the form of a discussion. The discussion provides more opportunities for intellectual and creative development of schoolchildren through mastering their foreign language communicative competence. The chapter touches upon the peculiarities of competency-based approach, learning motivation and use of the discussion method in teaching. The responsibilities of a teacher at the stages of planning, moderating and the final stage are highlighted. Some examples of using the author's learning materials in foreign language lessons are given. In the research process, the following methods were used: analysis and generalization of domestic and foreign pedagogical, psychological and methodological literature on the use of discussion in teaching foreign languages; study and generalization of the pedagogical experience of teachers of the Evseviev Mordovia State Pedagogical University on the use of discussion in teaching foreign languages; quantitative and qualitative data processing methods. The effective discussion is a good practice for English speaking students. It helps to develop students' communication competence on all levels of language: phonetic, lexical and grammatical.

Keywords: Discussion. Foreign language teaching. Communicative competence. Educational technology.
\end{abstract}




\section{RESUMO}

A principal função da educação ligada às línguas estrangeiras é proporcionar aos alunos conhecimentos qualificados de acordo com a sua futura carreira. $\mathrm{O}$ artigo trata do problema da organização metodológica do ensino de uma língua estrangeira na forma de discussão. A discussão oferece mais oportunidades para o desenvolvimento intelectual e criativo de crianças em idade escolar através do domínio de sua competência comunicativa em língua estrangeira. $O$ capítulo aborda as peculiaridades da abordagem baseada em competências, motivação para a aprendizagem e uso do método de discussão no ensino. São destacadas as responsabilidades de um professor nas etapas de planejamento, moderação e na etapa final. Alguns exemplos de uso dos materiais de aprendizagem do autor em aulas de língua estrangeira são dados. No processo de pesquisa foram utilizados os seguintes métodos: análise e generalização da literatura pedagógica, psicológica e metodológica nacional e estrangeira sobre o uso da discussão no ensino de línguas estrangeiras; estudo e generalização da experiência pedagógica de professores da Universidade Pedagógica Estadual Evseviev Mordovia sobre o uso da discussão no ensino de línguas estrangeiras; métodos de tratamento de dados quantitativos e qualitativos. A discussão efetiva é uma boa prática para estudantes de língua inglesa. Ajuda a desenvolver a competência de comunicação dos alunos em todos os níveis da linguagem: fonético, lexical e gramatical.

Palavras-chave: Discussão. Ensino de língua estrangeira. Competência comunicativa. Tecnologia Educacional.

\section{RESUMEN}

La función principal de la educación relacionada con lenguas extranjeras es proporcionar a los alumnos conocimientos calificados de acuerdo con su futura carrera. El artículo trata el problema de la organización metodológica de la enseñanza de una lengua extranjera en forma de discusión. La discusión brinda más oportunidades para el desarrollo intelectual y creativo de los escolares a través del dominio de su competencia comunicativa en lenguas extranjeras. El capítulo aborda las peculiaridades del enfoque basado en competencias, la motivación del aprendizaje y el uso del método de discusión en la enseñanza. Se destacan las responsabilidades de un docente en las etapas de planificación, moderación y etapa final. Se dan algunos ejemplos del uso de materiales de aprendizaje del autor en lecciones de idiomas extranjeros. En el proceso de investigación, se utilizaron los siguientes métodos: análisis y generalización de la literatura pedagógica, psicológica y metodológica nacional y extranjera sobre el uso de la discusión en la enseñanza de lenguas extranjeras; estudio y generalización de la experiencia pedagógica de los profesores de la Universidad Pedagógica Estatal Evseviev Mordovia sobre el uso de la discusión en la enseñanza de lenguas extranjeras; métodos de procesamiento de datos cuantitativos y cualitativos. La discusión efectiva es una buena práctica para los estudiantes de habla inglesa. Ayuda a desarrollar la competencia comunicativa de los estudiantes en todos los niveles del idioma: fonético, léxico y gramatical.

Palabras clave: Discusión. Enseñanza de lenguas extranjeras. Competencia comunicativa. Tecnologia Educacional.

\section{INTRODUCTION}

Learning a foreign language is a mandatory part of educational process at school at different levels: children start to learn a foreign language in the primary school and continue up to the time they leave school. A foreign language is also a part of university curriculum. A great range of methods can be used while teaching a foreign language. There are some methods that can be applied at all levels of education, and there are some that are more effective when used while working with high schoolers or elementary school students only. The majority of methods were 
developed a long time ago, but new methods keep coming in use. However, traditional methods of teaching a foreign language are more widely-spread nowadays as they are easy and convenient to use. At each lesson, when a new topic is introduced, the structure of the lesson remains unchanged, and a teacher presents only that part of new material which requires the use of those skills and abilities that were acquired earlier. Taking into consideration this cyclical nature, traditional teaching methods are characterized by the lack of opportunities to increase the motivation in learners. Thus, old methods can't meet new educational requirements, and we need to set new methodological trends to intensify the process of acquiring communication skills and increase students' interest in studying.

In this regard, innovations in the organization of teaching a foreign language are designed to improve the content of education in Russia.

Currently, studying children, their personality and unique inner worlds are at the forefront. The main goal of a modern teacher is to choose the forms and methods of organizing the educational activities of students correctly so that they optimally correspond to the set goal of developing the child's personality.

Due to the situation there is a great need for creating some special conditions that will ensure the increase in the quality of the education provided by our educational system. The use of new technologies in organizing foreign language teaching is one of the means that can help achieve this goal.

Modern linguodidactics offers a number of personality-oriented pedagogical technologies, ensuring differentiation and individualization of teaching, taking into account the knowledge level of students (Safonova, 1996; Golushkova, 2006; Kern, 2005). At present, in our opinion, the most frequently encountered technology is the technology of discussion, since it is the technology that brings rather significant results in teaching a foreign language (Boyarkina \& Nelkina, 2017).

Discussion as a form of conducting a lesson is a well-known form of carrying out an education process that has a long history in pedagogy. Nowadays, the discussion is still widely used in education.

The superiority of this technology is explained by its ability to provide the development of communication skills in students, since the main goal of training is the formation of spontaneous speech of students but not the strict memorization of texts. An important role is played by such features of discussion as its structure and style, which enrich the communicative nature of the English lesson. These structural and stylistic features, accumulating in themselves knowledge from the past, cultural and historical facts of a specific linguocultural reality, significantly affect the structural design of the lesson as a whole, making students direct participants of the communication process. Therefore, the use of different relevant information when organizing a discussion can cause a response from the recipient, i.e. a student, which is the main goal of this type of activity, namely, to draw the student's attention to the conversation, to a particular topic of the English lesson.

Thus, the discussion method is considered the most effective one in terms of development of speech competence in students. This competence is an integral part of human culture. It is connected with the communication speech practice and characterized by the amount of information one can receive in the target language and their ability to detect the presence of a literary background of different genres in the speaker's utterance. It is important to say that the competence is developed to the extent a person needs to solve the main problems that arise during communication, in accordance with the speech and cultural norms of the language.

Discussion is one of the methods of interactive learning, and it is also gaining widespread use in the education system. The point of this method is to exchange views on a specific issue, which allows students to learn how to express, to defend their opinions and listen to others.

A modern foreign language lesson is communicative in nature, i.e. the purpose of the lesson should be communicative (Vetoshkin et al., 2020). It means it should be aimed at developing skills 
based on one of the types of speech activity. Thus, discussion is practice-oriented, since a language acts as both a means of reaching the goal and a goal itself - the development of speaking skills. Thanks to the method of discussion, students have the opportunity to expand their knowledge, to actualize intersubject connections, which will lead to the formation of a holistic picture of the world.

\section{LITERATURE REVIEW}

The development of discussion as the main form of arguing was started by V.G. Belinsky (1976-1982), T.N. Granovsky (1896), A.N. Radishchev (1999), N. G. Chernyshevsky (1950).

At present, such questions as How teachers should teach student to discuss? and How group discussions should be organized in class? are highlighted in the scientific works by N. D. Galskova (2004), E. I. Passov (2000), G. V. Rogova (1991), V. L. Skalkin (2012), A. Kitaygorodskaya (1992), M. A. Kovalchuk (2008), L. B. Burova (2011), R. Akerman and I. Neale (2011), L. Cinganotto (2019) and others.

In the scientific literature, you can find various interpretations of the term discussion. Let's consider a few of them.

As noted by M. A. Nadel-Chervinskaya, a discussion (from the Latin discussio, which means a study or an analysis) is a talk about any controversial problem when interlocutors have different opinions. Such talks can take place just when people meet for a private conversation, or they can be even printed (Nadel-Chervinskaya, Chervinskiy, 1995).

T. S. Panina defines a discussion as a public talk or free verbal exchange of opinions, judgments, ideas on any controversial issue, problem. According to the scientist, this type of work should contain these inalienable elements: a combination of a complementary dialogue and discussion-dispute, a clash of different positions (Panina, 2006).

One cannot but agree with M. A. Kovalchuk that a discussion is a public talk about any issue at a meeting, in the press, in a conversation. A characteristic feature of a discussion is the absence of a prepared beforehand text which a speaker just reads. Discussion means speaking spontaneously. Nevertheless, having the beginning of the topic prepared in advance and written is welcomed (Kovalchuk, 2008).

It is noteworthy that the new dictionary of methodological terms and concepts by $E$. G. Azimov and A. N. Shchukin reveals the concept of this method with particular precision. According to it discussion is a type of dialogical speech. It can be a public debate, covering some scientific issues or everyday problems. Discussion has two or more than two participants and they support different opinions on the problem being discussed. Thus, their judgments contradict one another. Discussion, especially its dialogical parts are emotionally colored whereas monological ones are quite rational and aimed at disclosing the factual essence of the opinion the speaker sticks to (Azimov, Schukin, 2010; Shchukin, 2003).

In the given study, it is proposed to adhere to the definition by the scientist M. V. Klarin. M. V. Klarin defines a discussion as interaction of a dialogical nature, during which a practical experience of participating in a group dispute and finding a solution of theoretical and practical problems by joint efforts is formed (Klarin, 1995).

\section{RESEARCH METHODOLOGICAL FRAMEWORK}

In the course of the research, a set of methods was used: theoretical (study and analysis of scientific literature, systematization of effective methods that contribute to the development of communicative competence in students); empirical (pedagogical observation); comparative, with the help of which the ways how to use discussion while teaching students a foreign language are cognized. An analysis of scientific and methodological literature was carried out in order to determine the effectiveness of teaching children through the use of discussion teaching methods. 


\section{RESULTS AND DISCUSSION}

Scientists have found out that discussions in foreign language lessons are conducted by teachers not as often as it should be.

Let's consider in more detail the tasks that contribute to formation of foreign language communicative competence.

The proposed assignments are compiled in accordance with the requirements of the Russian state educational standards of the new generation. The main purpose of this set of tasks is to develop students' discussion skills.

\section{Exercise 1.}

The ability to express your opinion and defend your position is a prerequisite for a successful discussion. At the beginning of each lesson, students are offered phrases to comment on. Students work with the provided statements at will, some can refute or supplement the classmate's point of view.

Here are some aphorisms. Do you share the authors' opinions? Please tell $u$ if you agree or disagree with them.

All the world's a stage, and all the men and women merely players (William Shakespeare).

To have another language is to possess a second soul (Charlemagne) (Ledneva, 2016).

Success consists of going from failure to failure without loss of enthusiasm (Winston Churchill) (Ledneva, 2016).

Learning is a treasure that will follow its owner everywhere (Chinese Proverb) (Ledneva, 2016).

Fall seven times and stand up eight (Japanese Proverb) (Ledneva, 2016).

There are no shortcuts to any place worth going (Helen Keller) (Ledneva, 2016).

Use the next phrases:

In my opinion / I think / To my mind / From my point of view / I believe / I suppose / As for me... / I'm sure probably / Something tells me / It was just my point of view.

\section{Exercise 2.}

The task is to compare information. This type of tasks promotes the development of intuition and guesswork in children.

There should be handouts containing proverbs in English, their literal translation and Russian equivalent on each desk. The task for the students is to put the three components together and give their own explanation of the proverb. Additions from the other students are welcomed.

We will work with some proverbs about food. I've chosen this topic because it is very important for people. Try to find their Russian equivalent and translation:

1. English proverb: Between the cup and the lip a morsel may slip (Ledneva, 2016).

Translation: Кусочек может упасть, пока его несёшь от чашки ко рту (in Russ.) (Ledneva, 2016).

Russian equivalent: Не говори гоп, пока не перепрыгнешь (in Russ.) (Ledneva, 2016).

2. English proverb: Don't make your sauce until you have caught the fish (Klarin, 1995).

Translation: Не готовь соус до того, пока не поймал рыбы (Ledneva, 2016).

Russian equivalent: Медведя не убив, шкуры не продавай. Цыплят по осени считают (Klarin, 1995).

3. English proverb: After meat comes mustard (Ledneva, 2016).

Translation: После ужина горчица (in Russ.) (Ledneva, 2016).

Russian equivalent: После драки кулаками не машут (in Russ.) (Ledneva, 2016).

4. English proverb: Better some of the pudding than none of the pie (Ledneva, 2016). 
Translation: Лучше получить немного пудинга, чем вообще не получить пирога (in Russ.) (Ledneva, 2016).

Russian equivalent: Лучше синица в руках, чем журавль в небе (in Russ.) (Ledneva, 2016).

\section{Exercise 3.}

The task is to comprehend the text, to analyze and synthesize the information give in it. The text is taken from the textbook "Robin MacWizard's diary" (Kaufman, 2016). After reading and translating the text, children are asked some additional questions:

1. Who wrote the diary? What do you know about him? Is he the main character of the story?

2. Why did Robin decide to write a diary? And what about you? Do you keep a diary? Do you allow other to read your diary where your thoughts, ideas, and emotions are written? Describe your diary (the cover, the size of your diary). When do you make entries in your diary? If you do not have a diary, tell why?

3. Why is the diary addressed to an unknown friend? When you make entries in your diary, do you address to someone? Do you like to share your thoughts with someone?

4. How many passengers were there on board? Imagine yourself being a passenger of this ship for the first time. Describe your emotions. What would you wear if you went on a voyage? It was not the same, was it?

5. What was the name of the ship? Do you know the names of the famous ships?

6. Who were the Saints? Who were the Strangers? Do you think they belonged to the same class? What is your opinion on the differences between them?

7. Why did they decide to leave England? Was it the right decision? What did you offer for their situation?

8. Who was the leader of the Saints? Tell his three main character traits. Are you a leader in the class, among your friends?

9. When did they see land? Describe their emotions at the moment. Don't you think they might believe it to be a new chance for them to start a new life?

10. Was their leader a remarkable man? Why? Why not? Give the definition of the word "remarkable". What are other people you can call remarkable? Are you a remarkable person?

12. Where did they land? Was it safe?

13. Why did they land at Cape Cope? Do you know anything about this place? Was it an island or not?

14. What is the Mayflower Compact? Was he dangerous? Tell everything you know about him.

15. Who was chosen as a governor? Please, describe his appearance and character.

16. What was the decision made by the Pilgrims?

17. What were the reasons for the main characters to leave Cape Cope?

18. What was the place they ended up in\& If you had such an opportunity, would you like to move to a place like that?

19. Was the first place they settled in better than the second one? Explain your opinion.

20. What was the reason for so many people to have died? What would you advise to those who survived?

21. Do you approve the way the Pilgrims chose to survive? Do you think it to be normal for our time or not?

22. Describe the first Indian the characters of the story met first? What can you tell about him?

23. Did the Pilgrims trust him? Was he an honest man?

24. Was it the right decision to make an agreement with the Indians? Could they have found another way out? 
25. When did the Mayflower leave for England? Was it a good decision?

\section{Exercise 4.}

This exercise will help students learn how to write sample questions that they can ask passers-by in the country of the target language (UK, USA) to reach a place they are looking for.

Rob and Mark told Rosy about their trip to New York. Now it is your turn. Imagine you are in New York, and you want to visit some place. It can be Fifth Avenue, Broadway, "the Great White Way", Central Park, etc. Tell us why you want to visit this place. Look at the map and make up your own route. During your travelling you will meet strangers (your classmates), ask them about the route you need to follow to get.

For asking:

Can (Could) you tell me where ... is?

Excuse me, how do I get to ...?

For explaining the way:

Turn left (right)...

On the left (right) side...

It is opposite the...

It is between the ... and the...

It is on the corner...

Go up (down) the Street...

Go straight on...

Go past...

Keep going until you see...

\section{Exercise 5.}

The task (of a dialogical nature) is aimed at applying strategies of argumentation and persuasion. The knowledge needed is the vocabulary on the topic "Hello America!".

One of your friends wants to contribute an article to the school newspaper. The theme is "The most beautiful place in New York". He will ask questions to know your opinion and take some notes.

\section{Exercise 6.}

This exercise is not only about using the vocabulary under study but also about developing skills needed while getting out of a difficult situation.

You work in a guide company. You are to sell the last ticket in order to be promoted. But there is a problem: all the clients reject the proposal because of a high price. Find the arguments and persuade your client (friend) to buy this ticket.

\section{Exercise 7.}

Firstly, children are to study the vocabulary of the module (Unit 1). Then, they are encouraged to tell about different types of places on their own (Kaufman, 2016), and give their own definitions of the terms. Finally, each pair of students (sitting at one desk) is given a sheet of paper with the definitions from the dictionary, and the task is to match the definitions and terms.

As you know, there are different kinds of places (town, square, building, street, subway, road, avenue, downtown, uptown, district, pedestrian crossing, park, restaurant, shop, bank, post office, cinema, library, theatre, hospital, police station, fire station, school, museum, circus). Let's speak about them and describe. What places do you like and why?

Now you get definitions of these kinds of places. Try to match them with the words we've just talked about: 
- a structure such as a house, church, or factory, that has a roof and walls;

- a large open area in the centre of a town or city, usually in the shape of a square, or the buildings surrounding it;

- a path for people to walk under a road or railway;

- to or in the centre or main business area of a town or city;

- an area of a city that is away from the centre, especially one where the streets have larger numbers in their names and where people have more money;

- an area of a town or the countryside, especially one with particular features;

- a specially marked place for people to walk across the road;

- a place where you can buy and eat a meal;

- a business that keeps and lends money and provides other financial services;

- a place where you can buy stamps, send letters and packages etc.;

- a building in which films are shown;

- a large building where sick or injured people receive medical treatment;

- a building where the equipment used to stop fires burning is kept, and where firefighters stay until they are needed;

- a place where children are taught;

- a group of people and animals who travel to different places performing skillful tricks as entertainment (Cronin, 2006).

Now let's go directly to the discussion task we developed on the topic "Two ways of traveling: trips organized by the tourist agency and trips organized independently".

The purpose of the discussion is summing up and consolidating the material on the topic and practicing communication skills in monological and dialogical speech in the form of discussion.

The practical task is applying communication skills for dealing successfully with a given task from a real life.

The educational tasks are 1) to keep developing dialogical speech skills while practicing certain grammatical structures in speech; 2 ) to activate and improve the current vocabulary of the students.

The development tasks are 1) to keep developing imagination, the ability to express personal attitude to a particular issue; 2 ) to work on the ability to prove your point of view, to find your own ways of solving a problem; 3 ) to give stable positive emotions and facilitate students' personal activity.

The educational tasks are 1) to foster a respectful attitude towards strangers in students; 2 ) to develop the ability to interact and the ability to keep up a conversation.

It is necessary to create an appropriate working environment for a discussion to be successful. When organizing a debate, it is logical to place the desks of the students, that will be divided into two groups, opposite one another. This furniture rearrangement has a stimulating effect on the children; it is believed that this makes it easier for them to get into their roles.

Before you start discussion itself a teacher should work out a set of rules for all of the participants to follow. It is great when students participate in this activity. The set of rules may include the following points:

1. Do not interrupt!

2. Listen to the points of view of all discussion participants respectfully, even if they contradict your opinion!

3. Refrain from impolite attacks on your opponents!

4. Point out the shortcomings in your opponent's opinion, not in his or her personality!

5) Restrain emotions! Do not shout!

After working out the rules, you should proceed to the stage of the discussion. 
The first step is introduction. There should be an introductory speech pronounced by the teacher. It is a preamble to improve motivation, to stimulate activity and create a needed emotional background.

Good morning, pupils! I'm glad to see you. Sit down, please. Students, do you like travelling? What countries have you already visited? Do you know the meaning of the phrase "travelling savage"? Who can explain it? Who has such an experience? Today we will talk about two ways to travel: trips organized by a tourist agency and trips organized independently.

Now, you have to prove that your method of travelling is the best. List the benefits of your method and disadvantages of your opponents' one. You have 10 minutes to organize your ideas. After that we will start our discussion.

The second step is preparation. The students form two groups, each focusing on arguments and counterarguments. Some time is given for them to get prepared.

To help the students generate ideas, you can write some keywords on the board, such as: price, choice, time, risks, accessibility, organization, language, safety, etc.

The third step is discussion itself. The groups take turns presenting advantages of their way of travelling. After each statement, opponents should ask additional question and try to prove the opposite, using a list of shortcomings, which they have already prepared in advance.

The third step is summation. Students are invited to watch a video about a trip to New York. After that a teacher should sum up the results. The teacher is to say some final words. It can be just a short speech that concludes everything that has been said and, most importantly, indicates the end of the discussion.

Today I liked the way you've worked. You gave fine arguments, asked and answered different questions, followed etiquette. Your grammar was proper.

What have you known today?

I think it was a great discussion. I hope this lesson was useful for you. Thanks for your work.

When the lesson is over, the teacher should analyze it. The students may also participate in this activity. Special attention should be paid to the following points:

1) the content of utterances made by students while discussing;

2) the form of these utterances;

3) the feelings expressed by speakers while presenting their opinions and arguing.

As for the content of the utterances, they are analyzed in terms of their validity, level of argumentation, way the judgments were presented. It should be mentioned if all of the utterances were to the point or not.

In addition to the discussion given as an example above, the following questions can be brought up on the topic Travelling:

1) Places for rest: on the beach or in the mountains. What would you prefer?

2) Domestic tourism: for and against.

3) Favorite means of travelling.

\section{CONCLUSION}

The use of discussion in teaching a foreign language makes it possible for students to activate the process of mastering a foreign language and show the potential they have not only in this particular subject, but also in other spheres, such as public speaking, conflict management, etc. The technology of discussion contributes to the creation of special atmosphere in class that helps students to understand new language material easily. This form of group work also provides students with the excessive amount of speech practice that is the key to successful acquisition of the foreign language communicative competence. Discussion is, as well, a great way for students to get some experience they may need in real life later as discussions may touch some really relevant 
problems of modern society or include some practice-oriented tasks that imitate live communication.

In addition, while working in small groups, students use self-learning and mutual learning. These two kinds of leaning not only bring some changes in educational routine, they also motivate students to work better, stimulate their mental activity, provide the obtaining of a solid grasp of educational material.

In conclusion, it should be noted: the numerous work experience and observations of practicing teachers on this issue have shown that discussion as a teaching method is sure to have a positive impact on the process of teaching and learning a foreign language. Its main advantage can be explained by the fact that discussion is capable of getting all of the students involved in the activity and makes them more motivated than ever. It cannot choose but affect positively the effectiveness and intensity of educational process.

Authors' Contributions: Vetoshkin, A. A.: conception and design, acquisition of data, analysis and interpretation of data, drafting the article, critical review of important intellectual content. Piskunova, S. I.: conception and design, acquisition of data, analysis and interpretation of data, drafting the article, critical review of important intellectual content. Boyarkina, L. M.: conception and design, acquisition of data, analysis and interpretation of data, drafting the article, critical review of important intellectual content. Davydova, E. A.: conception and design, acquisition of data, analysis and interpretation of data, drafting the article, critical review of important intellectual content. Nikishina, O. A.: conception and design, acquisition of data, analysis and interpretation of data, drafting the article, critical review of important intellectual content. All authors have read and approved the final version of the manuscript".

Ethics Approval: Not applicable.

Acknowledgments: The work was supported by the grant to conduct research in priority areas of research activities of partner universities on network interaction (Bashkir State Pedagogical University and Mordovia State Pedagogical University) on the theme "Features of teaching English with the help of new educational technologies".

\section{REFERENCES}

Akerman, R., \& Neale, I. (2011). Debating the evidence: An international review of current situation and perceptions. The English-Speaking Union. Retrieved from: https://debate.uvm.edu/dcpdf/ESU_Report_debatingtheevidence_FINAL.pdf

Azimov, E.G., \& Schukin, A.N. (2010). Modern dictionary of methodical terms and definitions (theory and practice of language teaching). Moscow: IKAR.

Belinsky, V.G. (1976-1982). Collected works. In 3 volumes. Moscow: Fiction Publishing.

Boyarkina, L.M., \& Nelkina, A.A. (2017). Features of use of discussion methods on the lessons of the English language. Nauchnoe obozrenie, 2, 106.

Burova, L.B. (2011). Discussion as a means of forming communicative competence. Science and Modernity, 8, 214-220.

Chernyshevsky, N.G. (1950). The anthropological principle in philosophy. Moscow: Progress Publishers.

Cinganotto, L. (2019). Debate as a teaching strategy for language learning. Lingue Linguaggi, 30, 107. http://dx.doi.org/10.1285/i22390359v30p107

Cronin, A.J. (2006). Macmillan English Dictionary for Advanced Learners. Oxford: Bloomsbury Publishing Plc.

Galskova, N.D. (2004). Theory of Teaching Foreign Languages: Linguo-didactics and Methodology. Moscow: Publishing Centre "Academy".

Golushkova, N.M. (2006). Diskussion im Unterricht. Foreign Languages at School, 4, 101-103.

Granovsky, T.N. (February 8, 1896). On the current state and significance of world history: Speech at the ceremonial act of the Imperial]. Saint Petersburg.

Kaufman, M.Yu. (2016). Robin MacWizard's Diary. Stories about the History of the USA. Reader for the 9th grade. Moscow: Titul.

Kern, K. (2005). Developing a test of communicative competence for English as second language students at the 
college level. Portland: Portland State University.

Kitaygorodskaya, G.A. (1992). Intensive foreign language teaching: theory and practice. Moscow: Vyshaya shkola.

Klarin, M.V. (1995). Innovation in the global pedagogy: learning through research, games and discussions. (Analysis of foreign experience). Riga: Experiment.

Kovalchuk, M.A. (2008). Discussion as a means of teaching foreign language communication. Moscow: Vyshaya shkola. Ledneva, L. (2016). 60 quotes in English for the development of erudition and vocabulary replenishment. Lifehacker. Retrieved from: https://lifehacker.ru/2016/05/19/60-quotes-in-english

Nadel-Chervinskaya, M.A., Chervinskiy, P.P. (1995). Great Dictionary of Foreign Words. Rostov-on-Don: Phenix.

Panina, T.S. (2006). Modern ways to activate learning: Doctoral Dissertation. Moscow.

Passov, E.I. (2000). Program - the concept of communicative education in another language. Moscow: Enlightenment.

Radishchev, A.N. (1999). Selected Works. Moscow-Leningrad.

Rogova, G.V. (1991). Methods of Teaching English at secondary school. Moscow: Prosveschenie.

Safonova, V.V. (1996). Learning languages of international communication in the context of the dialogue of cultures. Voronezh: Istoki.

Shchukin, A.N. (2003). Methods of teaching Russian as a foreign language. Moscow: Vysshaja shkola.

Skalkin, V.L. (2012). Educational discussion as a means of developing unprepared speech. Foreign Languages at School, 8, 18-25.

Vetoshkin, A.A., Piskunova, S.I., Kashtanova, I.I., Pronkina, V.M., Radin, A.M. (2020). Methodical Support in Additional Language Education. International Journal of Applied Exercise Physiology, 9(2), 181-192.

Received: 11 October 2021 | Accepted: 22 January 2022 | Published: 25 February 2022

This is an Open Access article distributed under the terms of the Creative Commons Attribution License, which permits unrestricted use, distribution, and reproduction in any medium, provided the original work is properly cited. 